\title{
EMISSION OF PARTICULATES AND CHOSEN GASEOUS EXHAUSTS COMPONENTS DURING A DIESEL ENGINE STARTING PROCESS
}

\author{
Andrzej KURANC ${ }^{1}$, Tomasz SŁOWIK ${ }^{1}$, Jacek WASILEWSKI ${ }^{1}$, \\ Joanna SZYSZLAK-BARGLOWICZ1, Monika STOMA ${ }^{1}$, Branislav ŠARKAN ${ }^{2}$ \\ ${ }^{1}$ University of Life Sciences in Lublin, POLAND \\ ${ }^{2}$ University of Zilina, SLOVAKIA \\ E-mail of corresponding author: andrzej.kuranc@up.lublin.pl
}

Keywords: exhaust emission, diesel engine, start-up, sustainable agriculture

\begin{abstract}
It is very important to reduce harmful emissions in rural areas. One of the ways is to replace old tractors and farm machinery with the modern, equipped with engines of the highest standards. However, the cost of such replacement is very high and not always acceptable, especially for smaller farmers, nevertheless, due to the needs of sustainable agriculture it should be kept up. This work focuses on exhaust harmful emission during a start-up of a diesel engine installed in a small agricultural tractor. Based on measurements and recorded data, calculations of exhaust gas emission were carried out. The results indicate that the engine starting process, and its initial temperature, have a considerable impact on the emissions during the analyzed operation period. The most important is cold start process which is responsible for most harmful pollutants emission during the initial period of engine work. The temperature of cold start is also noticeable for cold starts and for worm starts as well.
\end{abstract}

\section{INTRODUCTION}

The growing problem of increasing air pollution is more and more the outstanding issue in the agrarian areas. Tractors and agricultural machinery used for the field work and transport purposes constitute one of the emission sources. This paper regards ecological aspect of operating a tractor concerned with its engine start-up and its work right after the start. Engine start-up is especially significant in terms of reliability (Droździel \& Krzywonos, 2009). On the other hand it is an extremely hazardous process in terms of emission of toxic substances (Fan, Bian, Lu, Li, \& Deng, 2012; Kuranc, 2008; Kuranc \& Tarasińska, 2009). Emission of exhaust gases is influenced by a number of construction design-related factors that are also very important operation-related factors (Mysłowski, 1996). Fuel and engine oils as well as engine wear-and-tear (Ambrozik, Ambrozik, \& Lagowski, 2015; Wolak \& Zając, 2017; Zając \& Węgrzyn, 2008) are extremely significant for efficiency of the engine start-up, and in particular for preparation of proper air/fuel mixture as well as airtightness of combustion chamber of a cold engine and minimize resistances during the start-up. A tractor or machinery wearand-tear as well as its technical advancement related to exhaust gas after treatment methods used for neutralization purposes matter, too (Merkisz, Lijewski, \& Walasik, 2010; Sarkan, Stopka, Gnap, \& Caban, 2017). Although a successive replacement of agricultural machinery with new and more ecological one has been being observed for several years now, numerous farmsteads still use machinery and equipment that is obsolete in terms of construction (Lorencowicz, 2016; Skudlarski, 2017). URSUS 2812 agricultural tractor, very popular in the $80 \mathrm{~s}$ and $90 \mathrm{~s}$ of the 20th century, still manufactured until 2009, is an example of quite simple construction that was examined.

\section{STUDY OBJECTIVE, OBJECT AND SUBJECT MATTER}

The aim of the study was to measure the emission of particulate matter and some of the gas components emitted during the engine start-up and right after the start when the 
engine was idling. For the purpose of the study the instruments such as the MPM4 particulate matter measuring instrument and the MGT5 exhaust gas analyser had been adjusted for continual analysis, and equipped with a computer hardware and software for recording data purposes.

The study covered measurements and analysis as well as track recording of the following parameters:

- engine rotational speed - RPM, $\left(\mathrm{min}^{-1}\right)$,

- engine oil temperature - T, $\left({ }^{\circ} \mathrm{C}\right)$,

- emission of particulate matter - PM (Particle Matter), $\left(\mathrm{mg} \cdot \mathrm{m}^{-3}\right)$,

- volumetric shares of chosen gas components - $\mathrm{CO}$ carbon oxide, $\mathrm{CO}_{2}$ carbon dioxide, $\mathrm{O}_{2}$ oxygen, $(\%)$, and $\mathrm{HC}$ unburned hydrocarbons, $\mathrm{NO}_{\mathrm{X}}$ nitrogen oxides, $(\mathrm{ppm})$,

- $\lambda$ air excess coefficient computed by the analyser.

The measurement results were recorded at the frequency of $1 \mathrm{~Hz}$.

Next, the emissions of the distinguished exhaust gas components were computed.

\section{METHODS}

URSUS 2812 (MF235) agricultural tractor equipped with Perkins AD3.152 self-ignition engine was the object of the study (ZPC URSUS, 1987). Before the study was commenced, the tractor and its engine alongside power supply system, intake system, cooling system, lubrication system, start-up system, and the battery had undergone check-up procedures. Filters and exploitation fluids had been replaced and the injection pump and the fuel injectors had been checked and regulated. After having completed the check-up procedures, the engine load tests were conducted by means of the dynamometer stand to assess whether the condition of the engine was good.

For the purpose of the exhaust gas study, the 5-component gas analyser of „0" class type MGT5 (MAHA, 1999) was used, additionally measuring the rotational speed and engine oil temperature. The MPM4 particulate matter measuring instrument was aligned with the exhaust gas analyser (MAHA, 2008). The aforementioned instruments, including the PC and dedicated software, made up the measuring-and-recording system. The research stand was located outside the laboratory in order to take advantage of natural temperature conditions.

Within the start-up time limits, engine stabilisation time before start ranges from 6 hours to 12 hours (Mysłowski, 1996). During the aforementioned measurements and analyses, before every measurement for the cold start-up, the tractor had been pre-conditioned in ambient conditions for approximately 20 hours. The temperature of respective parts and exploitation fluids at the moment of the cold start-up was assumed to be equal to the ambient temperature. Measurements during the so called warm start-up were conducted after the measurements for the cold start-up, given the same surrounding, had been completed.

The recorded results in relation to the data on air composition and fuel combustion process formula have allowed to define the composition of exhaust gases for the engine under consideration under the specific conditions. Details on the method of computing the mass volume of emission of respective components had already been elaborated upon (Kuranc, 2015). 


\section{RESULTS}

Phenomena occurring in the course of starting a combustion engine are complicated and depend on a sequence of factors. The thorough analysis of the impact of the first fuel injection upon emission during the start-up has been presented (Fan et al., 2012). Our analyses refer to a longer period of time. In the Figure 1 the print screen of recorded parameters for the cold start-up in the ambient temperature of $5^{\circ} \mathrm{C}$ has been presented. Upon the first fuel injections, unburned hydrocarbons (HC), being the proof of misfiring fuel during first cycles of turning the engine shaft, are first to appear. The maximum value of their concentration stands approximately at $55 \mathrm{ppm}$ for $5^{\circ} \mathrm{C}$. Next we have observed the decrease in the concentration of oxygen $\left(\mathrm{O}_{2}\right)$ in exhaust gases and appearance of carbon dioxide $\left(\mathrm{CO}_{2}\right)$ and carbon oxide $(\mathrm{CO})$, which is the proof for the combustion process. Carbon oxide alike hydrocarbons prove imperfection of the combustion process and local lack of oxygen. It is evident within seconds after the startup when its emission volume reaches the peak value of $0.64 \%$. Later on, during the idling, the concentration of $\mathrm{CO}$ is stabilised at $0.05 \%$.

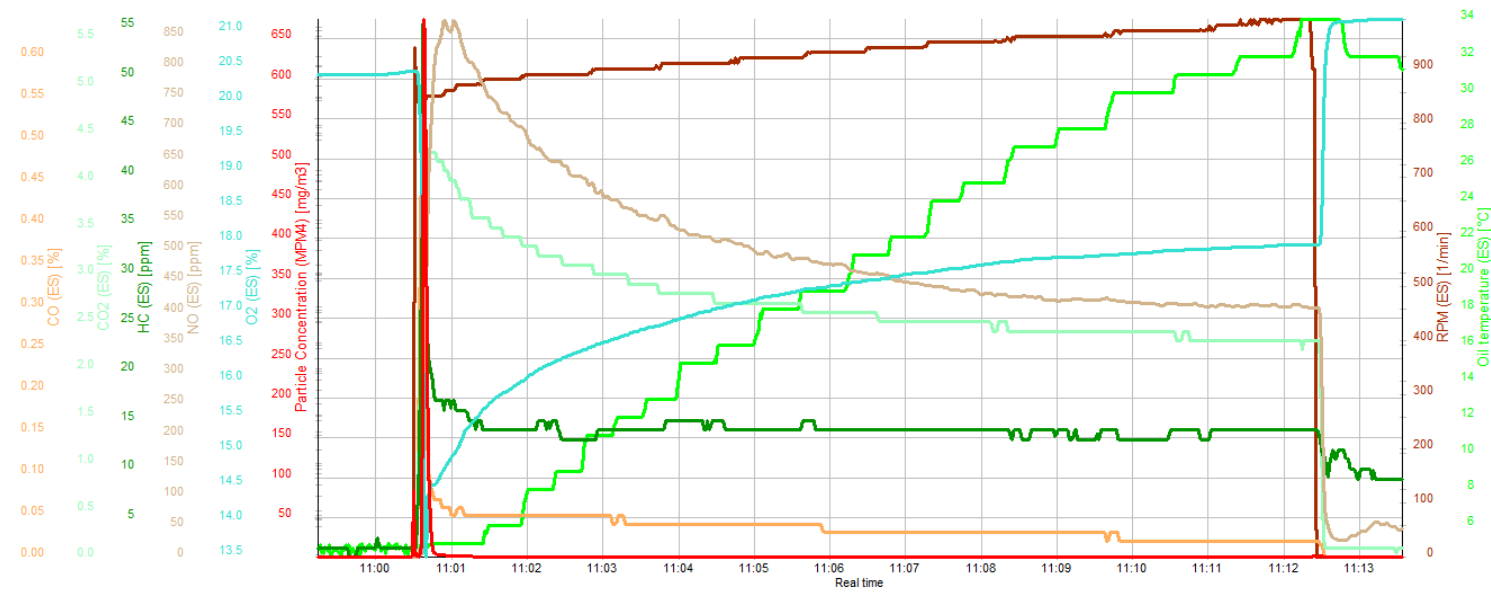

Figure 1. AD3.152 engine fumes composition changes after a cold start at ambient temperature $5^{\circ} \mathrm{C}$ - software print screen MAHA EmissionViewer Version 1.0.4.380

At the start-up the emission of particulate matter (PM) is also pretty evident and its peak value reaches $670 \mathrm{mg} \cdot \mathrm{m}^{-3}$. Emission of PM and observed smokiness mainly result from high temperature deterioration of fuel particles and local unburning and then coagulation and conglomeration of PM. In the absence of external engine load, such a situation is limited to first cycles of operations. In subsequent seconds, PM emission decreases and after a dozen of seconds after having started the engine, its value does not, exceed $10 \mathrm{mg} \cdot \mathrm{m}^{-3}$.

In the same period when carbon oxide and particles appear, nitrogen oxides (NOx) appear, too, and prove the combustion since they appear exclusively when there is high pressure and high temperature that accompany the burning process. However, the peak value of NOx emission (approximately 650ppm) is reached approximately 15 seconds later than that for hydrocarbons, carbon oxide or particles. This is caused by a very large influence of low temperature of the cylinder walls that absorb substantial quantity of heat and, in this way, hamper the process of creation of nitrogen oxides. However, their later decrease in concentration may be explained by means of diminishing resistance of motion of the engine being warmed up and thus diminishing fuel dose indispensable for 
keeping it in motion, which contributes to the decrease in maximum temperature and pressure, responsible for creation of NOx, in the cylinder.

Due to the emission of exhaust gases, it is worth comparing the cold and warm start-up of the engine (Figure 2). In the case of the warm start-up, the period, during which the emission of HC, CO, NOx and PM is higher, is shortened to last for a dozen of seconds. Therefore, the peak values of their concentration multiply. In the case of PM, they are ten times lower.

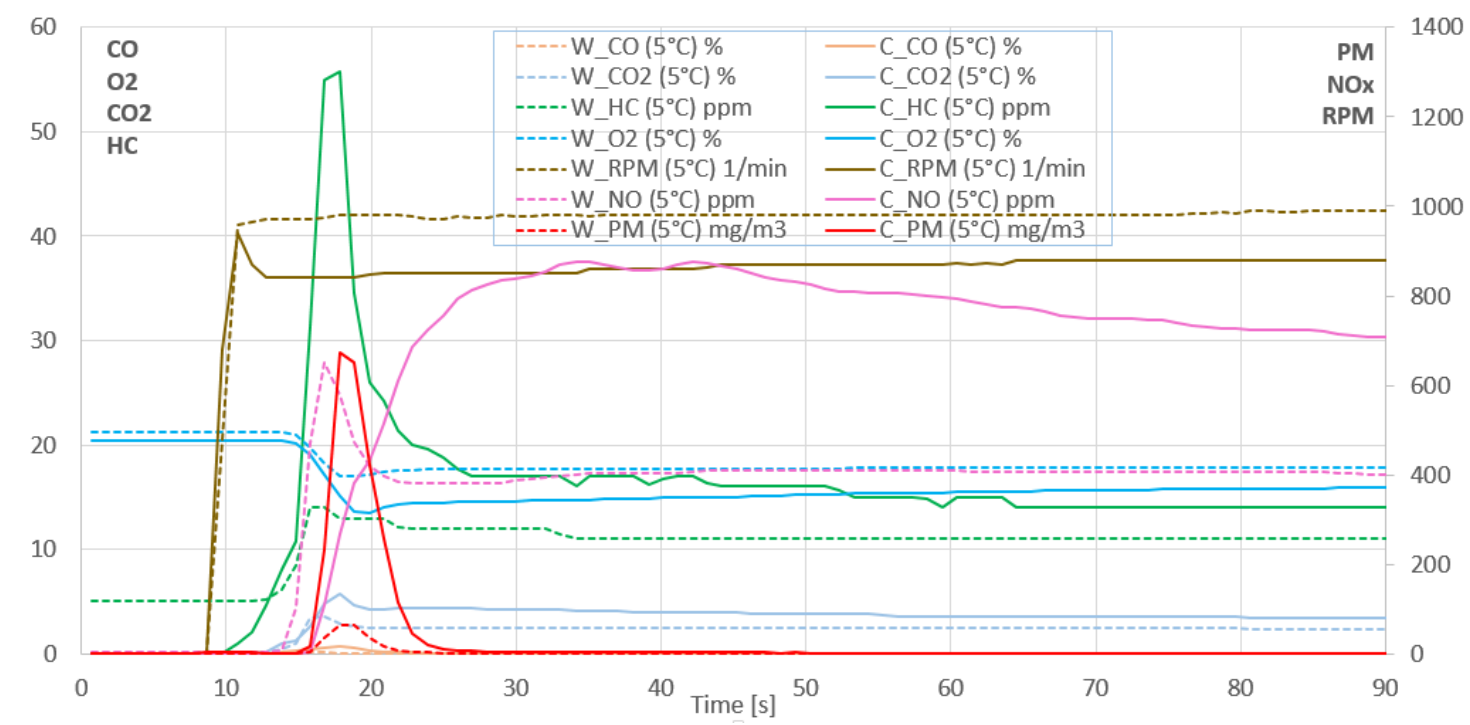

Figure 2. Volumetric shares of chosen fumes compounds at cold (C) and warm (W) startups within the first 90 seconds of work at ambient temperature $5^{\circ} \mathrm{C}$ for engine $\mathrm{AD} 3.152$

Summing up the emission in the beginning of operations of the engine, the table (Table 1) of mass emission of gas exhaust components for cold and warm start-ups in ambient temperature of $0^{\circ} \mathrm{C}$ and $5^{\circ} \mathrm{C}$ has been presented. The table has been drawn up in respect of first 90 seconds following the start-up on the basis of computations referring to the flow of exhaust gases and their composition.

Table 1. Emissions and fuel consumption at cold and warm startups within the first 90 seconds of work at ambient temperatures $0^{\circ} \mathrm{C}$ i $5^{\circ} \mathrm{C}$ for engine $\mathrm{AD} 3.152$

\begin{tabular}{|c|c|c|c|c|c|c|c|c|}
\hline & Total & $\mathrm{CO}_{2}$ & $\mathrm{O}_{2}$ & $\mathrm{CO}$ & $\mathrm{HC}$ & NOx & PM & Fuel \\
\hline & {$[\mathrm{kg}]$} & {$[\mathrm{kg}]$} & {$[\mathrm{kg}]$} & {$[\mathrm{g}]$} & {$[\mathrm{g}]$} & {$[\mathrm{g}]$} & {$[\mathrm{g}]^{*} 10^{-1}$} & {$[\mathrm{~kg}]^{*} 10^{-1}$} \\
\hline Cold 0 & 1.6454 & 0.0917 & 0.2967 & 1.5921 & 0.1054 & 1.3992 & 1.0507 & 0.2839 \\
\hline Cold 5 & 1.6453 & 0.0897 & 0.2886 & 1.3141 & 0.0797 & 1.4731 & 0.3751 & 0.2833 \\
\hline Warm 0 & 1.4339 & 0.0544 & 0.2877 & 0.4659 & 0.0454 & 0.9014 & 0.0317 & 0.1664 \\
\hline Warm 5 & 1.4330 & 0.0512 & 0.2888 & 0.4175 & 0.0477 & 0.7247 & 0.0408 & 0.1576 \\
\hline
\end{tabular}

The analysis of the figures (Figure 3 ) indicates that cold start-ups in temperature $0^{\circ} \mathrm{C}$ and $5^{\circ} \mathrm{C}$ are similar in terms of emission, which is also the case with warm start-ups. For cold start-ups largest differences may be spotted in the case of emission of particles of $105.07 \mathrm{mg}$ and $37.51 \mathrm{mg}(64 \%)$, respectively, carbon oxide of $1592.1 \mathrm{mg}$ and 1314.1 $\mathrm{mg}(17 \%)$, respectively, and hydrocarbons of $105.4 \mathrm{mg}$ and $79.7 \mathrm{mg}(24 \%)$.

In the case of warm start-ups, emission of hazardous substances is much lower than that for cold start-ups. The comparison of warm and cold start-up in temperature of $5^{\circ} \mathrm{C}$ for 
the period of 90 seconds indicates the reduction in the emission of PM by $89 \%, \mathrm{CO}$ by $68 \%$ and $\mathrm{HC}$ by $40 \%, \mathrm{NO}_{\mathrm{X}}$ by $51 \%$.

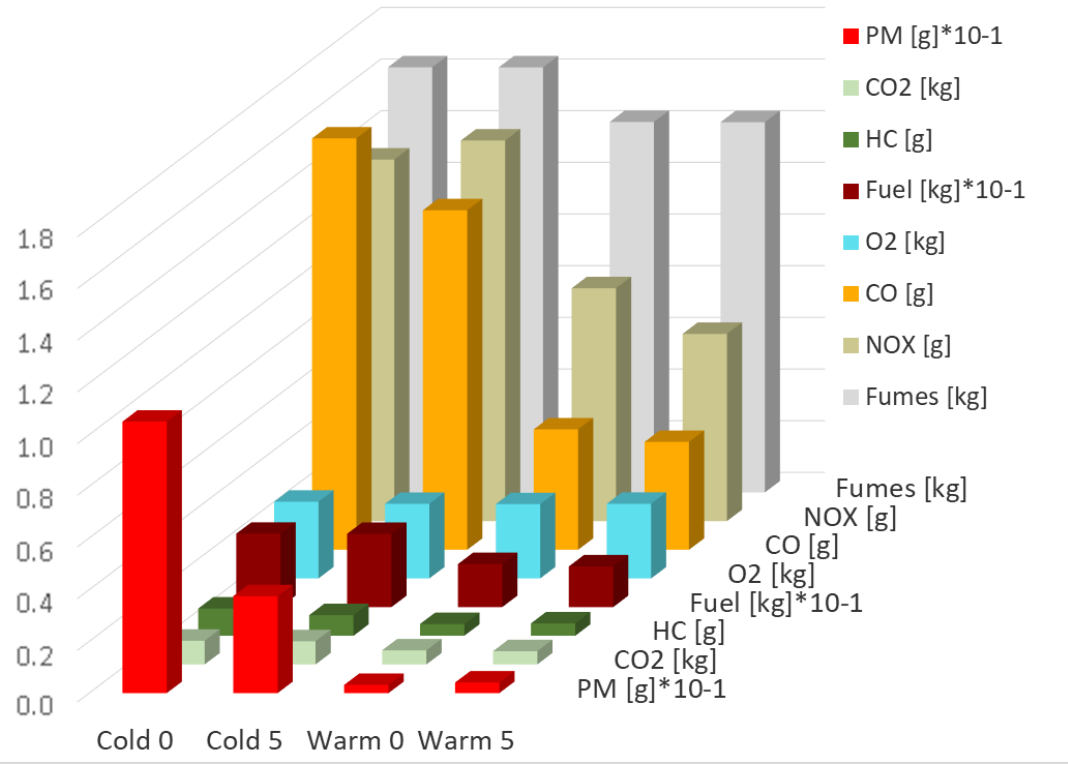

Figure 3. Emissions and fuel consumption at cold and warm startups within the first 90 seconds of work at ambient temperatures $0^{\circ} \mathrm{C}$ and $5^{\circ} \mathrm{C}$ for engine $\mathrm{AD} 3.152$

In the case of fuel consumption and emission of carbon dioxide, differences have also been considerable and have amounted to $44 \%$ and $43 \%$, respectively.

\section{CONCLUSIONS}

On the basis of the results, regarding the composition of exhaust gases during the startup and the following warming up period, the temperature of the engine at the start-up proves to substantially influence the emission of hazardous components of exhaust gases. As far as the period of 90 seconds is concerned, the differences in the emission for the cold and warm start-up have been extremely evident and have reached the value of $89 \%$ for particulate matter, $68 \%$ for carbon oxide, $40 \%$ for hydrocarbons and $51 \%$ for nitrogen oxides.

Due to the higher internal resistance of the cold engine that inter alia results from higher viscosity of lubricant, the start-up process may happen to be a very energy-consuming process (Mysłowski, 1996). In our study the aforementioned cold start has manifested itself by approximately $44 \%$ higher fuel consumption and related approximately $43 \%$ higher emission of carbon dioxide than the warm one.

The comparison sets of cold start-ups as well as the sets of warm start-ups have not indicated such considerable differences as it has been the case with the comparison of the cold and warm start-up, however such differences also occur and the impact of ambient temperature upon the emission and composition of exhaust gases is evident. Lower temperature of the cold start-up increases the emission of particles, carbon oxide and hydrocarbons whereas it doesn't increase the creation of nitrogen oxides, which can also be observed in this case. In the case of warm start-ups, differences are noticeable, however, they are not that considerable as in the case of cold start-ups. 
Taking into consideration the above, it is plausible to aim at reducing the emission and shortening idleness of the engine being warmed up as much as possible and at the same time one should pay attention to the manufacturer's recommendations in respect of the engine load when it is being warmed up.

Another way to reduce harmful emissions in rural areas is to replace old tractors and farm machinery with the new ones equipped with engines of the highest standards. However, the cost of such replacement is very high and is not always acceptable, especially for smaller farms. It is a long-lasting process requiring generations to be done, however, due to the needs of sustainable agriculture it should be kept.

\section{REFERENCES}

Ambrozik, A., Ambrozik, T., \& Lagowski, P. (2015). Fuel impact on emissions of harmful components of the exhaust gas from the CI engine during cold start-up. Eksploatacja i Niezawodność, 17(1), 95-99.

Droździel, P., \& Krzywonos, L. (2009). The estimation of the reliability of the first daily diesel engine start-up during its operation in the vehicle. Eksploatacja i Niezawodność, 4-10.

Fan, Q., Bian, J., Lu, H., Li, L., \& Deng, J. (2012). Effect of the fuel injection strategy on first-cycle firing and combustion characteristics during cold start in a TSDI gasoline engine. International Journal of Automotive Technology, 13(4), 523-531. https://doi.org/10.1007/s12239-012-0050-3

Kuranc, A. (2008). The ecological aspect of a cold and hot starting of a spark ignition combustion engine. Eksploatacja i Niezawodność, 40-44.

Kuranc, A. (2015). Exhaust emission test performance with the use of the signal from air flow meter. Eksploatacja i Niezawodność - Maintenance and Reliability, 17(1), 129-134. https://doi.org/10.17531/ein.2015.1.17

Kuranc, A., \& Tarasińska, J. (2009). The analysis of significance level of relation between ambient temperature and exhaust emission in the initial term of SI engine work. Teka Komisji Motoryzacji i Energetyki Rolnictwa, 9, 145-154.

Lorencowicz, E. (2016). Changes of Agricultural Tractors Prices in Poland in the Years 2000-2014. Roczniki Naukowe Stowarzyszenia Ekonomistów Rolnictwa i Agrobiznesu, XVIII(4), 163-166.

MAHA. (1999). Motor Gas Tester MGT 5 Five-Gas Tester. Technical Handbook. MAHA Maschinenbau Haldenwang GmbH \& Co. KG. Hoyen 20, 87490 Haldenwang.

MAHA. (2008). MPM4 Partikelmessgerat. Original-Betriebsanleitung. MAHA Maschinenbau Haldenwang GmbH \& Co. KG. Hoyen 20, 87490 Haldenwang.

Merkisz, J., Lijewski, P., \& Walasik, S. (2010). The Analysis of Non-road Vehicle Engine Operating Conditions in Terms of Emission Regulations. Eksploatacja i Niezawodnosc - Maintenance and Reliability, (1(45)), 42-48.

Mysłowski, J. (1996). Rozruch silników samochodowych z zapłonem samoczynnym. Warszawa: Wydawnictwa Naukowo-Techniczne.

Sarkan, B., Stopka, O., Gnap, J., \& Caban, J. (2017). Investigation of Exhaust Emissions of Vehicles with the Spark Ignition Engine within Emission Control. Procedia Engineering, 187, 775 - 782. https://doi.org/10.1016/j.proeng.2017.04.437

Skudlarski, J. (2017). Market of New and Used Agricultural Tractors in Poland in The Years 2012-2016. Roczniki Naukowe Stowarzyszenia Ekonomistów Rolnictwa i Agrobiznesu, XIX(1), 165-169. https://doi.org/10.5604/01.3001.0009.8359

Wolak, A., \& Zając, G. (2017). The kinetics of changes in kinematic viscosity of engine oils under similar operating conditions. Eksploatacja i Niezawodność - Maintenance and Reliability, 19(2), 260-267. https://doi.org/10.17531/ein.2017.2.14

Zając, G., \& Węgrzyn, A. (2008). Analiza zmian parametrów pracy silnika o ZS zasilanego mieszaniną oleju napędowego i estrów etylowych oleju rzepakowego. Eksploatacja i Niezawodność, 17-24.

ZPC URSUS. (1987). Ciągnik URSUS MF235, Instrukcja obsługi. Warszawa: Zrzeszenie Przemystu Ciagnikowego URSUS. 